\title{
Enhanced thermotolerance of photosystem II by elevated pore-water salinity in the coastal marsh graminoid Sporobolus pumilus
}

\author{
Brant W. Touchette ${ }^{1,2, *}$, Sarah R. Schmitt ${ }^{2,3}$, John W. G. Moody ${ }^{2}$ \\ ${ }^{1}$ Department of Biology, Elon University, Elon, North Carolina 27244, USA \\ ${ }^{2}$ Department of Environmental Studies, Elon University, Elon, North Carolina 27244, USA \\ ${ }^{3}$ Present address: Applied Research Associates, Arlington, Virginia 22203, USA
}

\begin{abstract}
In coastal marsh ecosystems, high salinities, anoxic waterlogged soils, and elevated summer temperatures often promote physiological strain that results in only a few tolerant halophytic species. Although not well understood, plant physiological responses to multiple stressors can be complex and may involve intensifying or offsetting reactions. In this study, we investigated physiological responses to combined salinity and high temperature in the coastal marsh graminoid Sporobolus pumilus (syn. Spartina patens). Specifically, we considered changes in plant-water relations and Photosystem II (PSII) behavior (involving chlorophyll [chl] a fluorescence) in heatshocked plants that were acclimated to different salinities $(0,15$, and $30 \mathrm{psu})$. Higher salinities fostered lower stomatal conductance $(g)$, lower leaf-water potential $\left(\Psi_{\text {leaf }}\right)$ and lower tissue-water content $(\theta)$, as well as decreased potential quantum yield $\left(F_{\mathrm{v}} / F_{\mathrm{m}}\right)$ and decreased excitation energy capture efficiencies of open reaction centers $\left(F_{\mathrm{v}}{ }^{\prime} / F_{\mathrm{m}}{ }^{\prime}\right)$. Heat-shocked plants acclimated to freshwater only had decreased $F_{\mathrm{v}} / F_{\mathrm{m}}$ and PSII performance index $\left(P I_{\mathrm{ABS}}\right)$. Interestingly, there were no changes in chl a fluorescent outputs in heat-shocked plants acclimated to moderate salinities, and minimal changes in plants acclimated to high salinities. Approximately $25 \%$ of the heat-shocked $S$. pumilus in freshwater revealed a K-step in their polyphasic chl a fluorescent transients (OJIP procedure); K-steps were not observed in salt-treated plants. This suggests that, for plants residing in freshwater, heat-shock promoted disturbances in the PSII reaction centers and, in some cases, disrupted the oxygen-evolving complex. These PSII disruptions were either absent or less intense in salinity-treated plants, indicating that acclimation to environmental salts may provide PSII thermostability in S. pumilus.
\end{abstract}

KEY WORDS: Photosynthesis $\cdot$ Chlorophyll fluorescence $\cdot$ Photosystem II $\cdot$ Heat stress $\cdot$ Salt stress

\section{INTRODUCTION}

Abiotic components in coastal marsh systems are highly stressful for most vascular plant species. Reduced and anoxic waterlogged soils with elevated summer temperatures and high environmental salinities promote selective pressures that result in the prevalence of only a few tolerant halophytic species (Ranwell 1972, Pezeshki \& DeLaune 1993). Environ-

${ }^{*}$ Corresponding author: btouchette@elon.edu mental salt is arguably among the most stressful of these factors as it often dictates the vegetative structure and function of coastal marsh communities (Noe \& Zedler 2000, Schröder et al. 2002, Wilson et al. 2015). Indeed, vascular plant zonations within salt marshes typically reflect unique patterns of salinity, including the competitive pressures among species with different salt tolerances (Adams 1963, Pennings et al. 2005, Touchette 2006). Although classified as

(C) The authors 2020. Open Access under Creative Commons by Attribution Licence. Use, distribution and reproduction are unrestricted. Authors and original publication must be credited. 
halophytes due to their relatively high tolerance to environmental salts, only a few coastal plant species are actually restricted to high saline conditions (Barbour \& Davis 1970, Partridge \& Wilson 1987, Touchette et al. 2019). Therefore, like glycophytes, many saltmarsh plants perform best in freshwater, and increases in environmental salts often result in greater physiological stress (Barbour \& Davis 1970, Touchette et al. 2012, Li et al. 2018). In a 10 wk study involving coastal graminoids, leaf chlorosis dramatically increased in Sporobolus pumilus when exposed to salinities $\geq 15$ in comparison to plants grown in freshwater (Touchette et al. 2019). Furthermore, soil salinities in coastal marshes can be highly variable, and in many cases salt marshes are most productive in areas with dilute surface waters and/or where groundwater mixing lowers overall saline conditions (Butzeck et al. 2015, Touchette et al. 2019). In coastal marshes of North Carolina (USA), for example, soil pore-waters can be highly diluted, with salinities ranging from 0.8 to 19 for high and low marsh areas, respectively (Touchette 2006).

Physiological strain associated with salt stress may include altered plant-water relations (e.g. decreased tissue water potential and lower stomatal conductance) and disruptions in photosynthesis, with increasing strain as salinity levels rise (Pearcy \& Ustin 1984, Drake 1989, Touchette et al. 2009a, Salpeter et al. 2012). A non-invasive tool useful in characterizing salinity-induced perturbations in Photosystem II (PSII), and hence photosynthesis, is chlorophyll a (chl a) fluorometry (Touchette et al. 2012, Dąbrowski et al. 2016, Kalaji et al. 2018). Chl a fluorescence outputs help characterize physiological modifications or impairments attributed to photodamage and/or photoprotection through reversible non-photochemical quenching (Cavender-Bares \& Bazzaz 2004). Common markers used in chl a fluorescence studies, such as potential quantum yield $\left(F_{\mathrm{v}} / F_{\mathrm{m}}\right)$ and excitation energy capture efficiencies of open reaction centers (RCs) $\left(F_{\mathrm{v}}{ }^{\prime} / F_{\mathrm{m}}{ }^{\prime}\right)$, have been useful in identifying changes in PSII attributable to a variety of environmental stressors including heat stress at moderately elevated temperatures (between 30 and $38^{\circ} \mathrm{C}$; Lu \& Zhang 2000). Another marker, the chl a performance index $\left(P I_{\mathrm{ABS}}\right)$, represents a more comprehensive metric that also employs fluorescence outputs while considering plant strain associated with photon absorption efficiency, excitation energy captured by PSII, active RC densities, and the likelihood that energy continues through photochemistry (Strasser et al. 2000, Thach et al. 2007).

Owing to the characteristically harsh abiotic conditions common to many coastal marshes, these systems provide a unique opportunity to explore how multiple environmental stressors influence the physiological behavior of resident vascular halophytes. However, plant responses to multiple stressors can be quite complex, as combined stress factors may promote intensified, overlapping, or antagonistic responses (Osmond et al. 1987, Aber et al. 2001, Lu et al. 2003). In general, stress associated with elevated salt or heat on PSII performance has been investigated in terrestrial plant species (e.g. Kalaji et al. 2014, Chen et al. 2016). Less attention has been directed towards understanding the combined effects of heat and salinity on PSII, especially in coastal marsh vegetation ( $\mathrm{Lu}$ et al. 2003, Yan et al. 2012). This lack of attention is unfortunate, as some studies on halophytes (e.g. Artemisia anethifolia L. and Suaeda salsa L.) growing in arid and semiarid regions with high soil salinities observed limited salt-induced PSII perturbations in comparison to glycophytes (Lu et al. 2003, Wen et al. 2005). Indeed, for these halophytes, salt-adaptation had improved thermotolerance within the PSII RCs and the oxygenevolving complexes (Lu et al. 2003, Wen et al. 2005).

A prominent salt-tolerant species that resides along the mid- and south-Atlantic coasts of North America is Sporobolus pumilus (Roth) P.M. Peterson \& Saarela (syn. Spartina patens (Aiton) Muhl.; Peterson et al. 2014). This C4 grass commonly occurs as dense monotypic stands within coastal marshes and dune swales, and has a relatively wide salinity tolerance (e.g. inhabiting both freshwater and brackish systems; Bertness 1991, Hester et al. 1996). Although its salt tolerance may differ among genotypes, studies suggest that this species can tolerate salinities greater than 45 psu (Hester et al. 1996, Salpeter et al. 2012). Despite the importance of salinity in shaping primary productivity and vegetation patterns in salt marsh systems, our understanding of how salinity modifies physiological processes of coastal halophytes remains limited (Touchette 2007, Touchette et al. 2019). Understanding how halophytes respond to and interact with environmental salts in combination with other stressors may provide new insights into coastal marsh primary productivity and species distributional patterns (Rozema et al. 1985, Touchette 2006). Therefore, the purpose of this study was to elucidate the combined effects of salinity and high temperature stress on $S$. pumilus. More specifically, we sought to determine if long-term acclimation to different salinity levels $\left(0,15,30 \mathrm{psu}_{\text {; comparable to }}\right.$ freshwater, moderate, and high salinities, respectively) would influence plant-water relations and chl a fluorometric assessments of PSII behavior of $S$. pumilus following a sudden heat-shock event. 


\section{MATERIALS AND METHODS}

\subsection{Culture and treatment conditions}

One yr old Sporobolus pumilus, originally germinated and grown in freshwater, were transplanted into $0.8 \mathrm{l}$ containers that were placed within $20 \mathrm{l}$ microcosms ( 2 containers per microcosm) under controlled greenhouse conditions (seasonal temperatures varied, but typically ranged between 15 and $35^{\circ} \mathrm{C}$, and relative humidity between 35 and $90 \%$ ). Each container was filled with natural sediments (approximately $10 \mathrm{~cm}$; sandy loam soil texture [55\% sand, $19 \%$ silt, $26 \%$ clayl), and water levels were maintained at 1 to $2 \mathrm{~cm}$ below soil surface. Shoot densities in each container were planted at levels comparable to natural systems (between 3700 and 4000 shoots $\mathrm{m}^{-2}$; Curtis et al. 1989).

Salinity treatments $(\mathrm{n}=8$ microcosms each for 15 and $30 \mathrm{psu}$ ) were initiated in mid-February by exchanging freshwater in randomly selected microcosms with artificial seawater (15 and $30 \mathrm{psu}$; Instant Ocean, Spectrum Brands: $\mathrm{Na}^{+}$and $\mathrm{Cl}^{-}$accounted for $86 \%$ of the total ions) over a $1 \mathrm{wk}$ period. This dualcontainer microcosm (0.8 l container within a $20 \mathrm{l}$ microcosm) allowed for easy exchange and maintenance of sub-surface porewater salinities. Another set of microcosms $(n=8)$ remained in pre-treatment freshwater conditions ( 0 salinity). The 24 microcosms were arranged in a randomized complete block within the greenhouse. Because of the physiological delay in $S$. pumilus when acclimating to saline soils (Salpeter et al. 2012), all plants were maintained at their respective salinities $(0,15$, or 30$)$ for 18 mo prior to initiating heat treatments. During that period, salinities were monitored from extracted interstitial waters twice a week using a refractometer and/or conductivity meter (Model 556 MPS; YSI), and water levels were held between 1 and $2 \mathrm{~cm}$ below soil surface. Temperature and humidity levels within the experimental greenhouse, as previously mentioned, varied seasonally and were comparable to first-year conditions.

In mid-August, individual microcosms were randomly selected to receive heat treatments $(\mathrm{n}=4$, for each salinity level). Heat shock was applied by placing selected containers in a large laboratory oven $(55 \mathrm{~cm} \times 45 \mathrm{~cm} \times 35 \mathrm{~cm}$, internal height, width, and depth; Model 40GC; Quincy Labs) at $45^{\circ} \mathrm{C}$ for $60 \mathrm{~min}$. The temperature and stress duration used in this study were consistent with other heat-shock experiments on vascular plants (Queitsch et al. 2000, Wahid et al. 2007, Mittler et al. 2012). Heat-treated plants were then relocated to the greenhouse and exposed to natural ambient light for $2 \mathrm{~h}$ prior to conducting $\mathrm{chl}$ a fluorescence measurements. During heat treatment, plants were kept in the dark to minimize potential stabilizing or damaging effects of light on PSII (according to Lu \& Zhang 2000). Un-heated plants were also maintained in the dark at ambient temperatures during that same 60 min period.

\subsection{Plant-water relations}

Leaf relative water content $(\theta)$ was evaluated immediately before and within $60 \mathrm{~min}$ of heat treatments. Percent water content was determined on young, fully extended leaves according to Barrs \& Weatherley (1962) as modified by Joly (1985) using the following equations:

$$
\theta=\left(W_{\mathrm{f}}-W_{\mathrm{d}}\right) /\left(W_{\mathrm{t}}-W_{\mathrm{d}}\right) \times 100
$$

where $W_{\mathrm{f}}$ is fresh weight, $W_{\mathrm{t}}$ is turgid weight, and $W_{\mathrm{d}}$ is oven-dry weight $\left(60^{\circ} \mathrm{C}_{i} \mathrm{n}=4\right)$. Turgid weights were determined by placing leaves in $50 \mathrm{ml}$ sealed vials containing de-ionized water and allowing the samples to reach full turgor in darkness. Leaf water potentials ( $\Psi_{\text {leaf }}$ ) of young, fully extended leaves were measured just before and within 60 min of heat treatments using a Scholander pressure chamber (Model 1000, PMS Instrument; Scholander et al. 1965).

Duplicate stomatal conductance $(g)$ measurements were determined on young, fully expanded leaves using a leaf porometer (model SC-1; Decagon Devices). This instrument uses steady-state diffusion to measure vapor flux between the leaf surface and the atmosphere. As with other plant-water parameters, leaf conductance was recorded prior to heat shock and within 60 min after treatment. The duplicate measurements were pooled into a single mean value during data analysis to avoid replication within experimental units (i.e. pseudo-replication).

\subsection{Chlorophyll fluorescence}

In this study, polyphasic chl a transients (OJIP procedure; see below) were used to quantify the flow of energy through PSII as described by Strasser \& Srivastava (1995) and Strasser et al. (2000). Fast chl a fluorescence was measured on young, fully expanded leaves before and after heat shock using a portable fluorometer (Fluorpen 100-Max, Photon Systems Instruments). Triplicate measurements from each experimental unit were pooled prior to data 
analysis to avoid replication within an experimental unit. Chlorophyll fluorescence transients were initiated by applying a continuous pulse $(3000 \mu \mathrm{mol}$ quanta $\mathrm{m}^{-2} \mathrm{~s}^{-1}$ ) of saturating blue light $(470 \mathrm{~nm})$ in plants acclimated to a dark room for more than $45 \mathrm{~min}$. The fluorescent signals were initially recorded at $10 \mu$ s intervals for the first $600 \mu s$, followed by progressively longer intervals over a period of $2 \mathrm{~s}$ resulting in 456 individual recordings (detector wavelengths between 697 and $750 \mathrm{~nm}$ ). For the OJIP transients, O refers to the initial fluorescence that occurred around $\sim 50 \mu \mathrm{s}$, J between 2 to $3 \mathrm{~ms}$, I at approximately $60 \mathrm{~ms}$, and $\mathrm{P}$ was the peak fluorescence intensity. These chl a fluorescent outputs were used to evaluate PSII behavior (using the JIP-test procedure; see Table 1 for parameter definitions), including the performance index $\left(P I_{\mathrm{ABS}}\right)$ :

$$
P I_{\mathrm{ABS}}=\left(\frac{1-\left(F_{\mathrm{o}} / F_{\mathrm{m}}\right)}{\left(M_{\mathrm{o}} / V_{\mathrm{j}}\right)}\right)\left(\frac{\left(F_{\mathrm{m}}-F_{\mathrm{o}}\right)}{F_{\mathrm{o}}}\right)\left(\frac{\left(1-V_{\mathrm{j}}\right)}{V_{\mathrm{j}}}\right)
$$

where $V_{\mathrm{j}}$ is the relative variable fluorescence at the J-step (equivalent to $\left[F_{\mathrm{j}}-F_{\mathrm{o}}\right] /\left[F_{\mathrm{m}}-F_{\mathrm{o}}\right]_{;} F_{\mathrm{o}}$ is initial fluorescence, $F_{\mathrm{m}}$ is maximum fluorescence, and $F_{\mathrm{j}}$ is fluorescence at the J-step) and $M_{\mathrm{o}}$ is the initial slope of the fluorescence kinetics (Thach et al. 2007, Živčák et al. 2008). For potential quantum yield $\left(F_{\mathrm{v}} / F_{\mathrm{m}}\right)$, variable fluorescence yield $\left(F_{\mathrm{v}}\right)$ was calculated as $F_{\mathrm{m}}-F_{\mathrm{o}}$. The efficiency of excitation energy captured by open PSII RCs $\left(F_{\mathrm{v}}{ }^{\prime} / F_{\mathrm{m}}{ }^{\prime}\right)$ was estimated fluorometrically by applying saturating light to light-adapted leaves (acclimated between 1000 and $1500 \mu \mathrm{mol}$ $\mathrm{m}^{-2} \mathrm{~s}^{-1}$ of natural sunlight for more than $90 \mathrm{~min}$ ).

\subsection{Statistical evaluation}

A repeated measures ANOVA (salinity $x$ heat $x$ time; using general linear models [GLMs]), with time as the repeated-measure factor, was used to evaluate plant-water relations data $\left(g, \Psi_{\text {leaf }}\right.$, and $\left.\theta\right)$ and summative fluorescent parameters $\left(F_{\mathrm{v}} / F_{\mathrm{m}}, F_{\mathrm{v}}{ }^{\prime} / F_{\mathrm{m}}{ }^{\prime}\right.$, and $\left.P I_{\mathrm{ABS}}\right)$. To compare fluorescent data derived from the OJIP protocol following heat shock, we used a 2-way ANOVA (salinity $\times$ heat; GLM procedure), with $V_{\mathrm{i}}$, $M_{0}, N, \mathrm{ABS} / \mathrm{RC}$, and $\mathrm{TR}_{0} / \mathrm{RC}$ (see Table 1 for definitions) log-transformed prior to statistical comparisons to satisfy normality and/or equal variance assumptions. Post hoc analyses were conducted using Tukey multiple-comparison tests when significant differences were identified by ANOVAs. All comparisons were performed using SPSS Statistics 20 software (SPSS 2011) and considered significant at $\alpha=0.05$.

Table 1. Chlorophyll a fluorescence outputs and polyphasic fluorescence transient parameters (from the OJIP procedure) used in this study. Descriptions and mathematical expressions (where applicable) are included for each parameter. PSII: Photosystem II; $\mathrm{RC}$ : reaction center; $Q_{\mathrm{A}}$ : primary quinone electron acceptor

\begin{tabular}{|c|c|}
\hline Parameter & Description \\
\hline$F_{\mathrm{j}}$ & Chl a fluorescence at the J-step (2 ms) \\
\hline$F_{\mathrm{m}}$ & Maximum chl a fluorescence \\
\hline$F_{\mathrm{m}}^{\prime}$ & Maximum chl a fluorescence in light-adapted plants \\
\hline$F_{\mathrm{o}}$ & Initial chl a fluorescence (50 $\mu \mathrm{s})$ \\
\hline$F_{\mathrm{v}}$ & Variable chl a fluorescence; $F_{\mathrm{v}}=F_{\mathrm{m}}-F_{\mathrm{o}}$ \\
\hline$F_{\mathrm{v}}{ }^{\prime}$ & Variable chl a fluorescence in light-adapted plants \\
\hline$F_{\mathrm{v}} / F_{\mathrm{m}}$ & Potential or maximum quantum yield of PSII; $F_{\mathrm{v}} / F_{\mathrm{m}}=\left(F_{\mathrm{m}}-F_{\mathrm{o}}\right) / F_{\mathrm{m}}$ \\
\hline$F_{\mathrm{v}}{ }^{\prime} / F_{\mathrm{m}}{ }^{\prime}$ & Efficiency of excitation energy captured by PSII open RCs \\
\hline$F_{\mathrm{v}} / F_{\mathrm{o}}$ & Maximum potential for primary photochemistry; $F_{\mathrm{v}} / F_{\mathrm{o}}=\left(F_{\mathrm{m}}-F_{\mathrm{o}}\right) / F_{\mathrm{o}}$ \\
\hline$M_{\mathrm{o}}$ & Net rate of RC closure; $M_{\mathrm{o}}=4\left(F_{300}-F_{\mathrm{o}}\right) /\left(F_{\mathrm{m}}-F_{\mathrm{o}}\right)$ \\
\hline$N$ & $Q_{\mathrm{A}}$ turn-over number; $N=S_{\mathrm{m}} \times M_{\mathrm{o}} \times\left(1 / V_{\mathrm{j}}\right)$ \\
\hline$S_{\mathrm{m}}$ & Energy needed to close all RCs; $S_{\mathrm{m}}=\left(\right.$ area between curve and $\left.F_{\mathrm{m}}\right) /\left(F_{\mathrm{m}}-F_{\mathrm{o}}\right)$ \\
\hline$V_{\mathrm{i}}$ & Relative variable fluorescence at the I-step; $V_{\mathrm{i}}=\left(F_{\mathrm{i}}-F_{\mathrm{o}}\right) /\left(F_{\mathrm{m}}-F_{\mathrm{o}}\right)$ \\
\hline$V_{\mathrm{j}}$ & Relative variable fluorescence at the J-step; $V_{\mathrm{j}}=\left(F_{\mathrm{j}}-F_{\mathrm{o}}\right) /\left(F_{\mathrm{m}}-F_{\mathrm{o}}\right)$ \\
\hline $\mathrm{ABS} / \mathrm{RC}$ & Absorption flux per $\mathrm{RC} ; \mathrm{ABS} / \mathrm{RC}=M_{\mathrm{o}}\left(1 / V_{\mathrm{j}}\right)\left(1 /\left(F_{\mathrm{v}} / F_{\mathrm{m}}\right)\right)$ \\
\hline $\mathrm{ET}_{\mathrm{o}} / \mathrm{CS}$ & Electron transport flux per excited cross section; $t=0 ; \mathrm{ET}_{\mathrm{o}} / \mathrm{CS}=\left(F_{\mathrm{v}} / F_{\mathrm{m}}\right)\left(1-V_{\mathrm{j}}\right)\left(\mathrm{ABS} / \mathrm{CS}_{\mathrm{o}}\right)$ \\
\hline $\mathrm{ET}_{\mathrm{o}} / \mathrm{RC}$ & Initial electron transport flux per $\mathrm{RC}_{i} t=0_{i} \mathrm{ET}_{\mathrm{o}} / \mathrm{RC}=M_{\mathrm{o}}\left(1 / V_{\mathrm{j}}\right)\left(1-V_{\mathrm{j}}\right)$ \\
\hline $\mathrm{RC} / \mathrm{CS}$ & Density of $Q_{\mathrm{A}}$ reducing PSII RCs; RC/CS $=\left(F_{\mathrm{v}} / F_{\mathrm{m}}\right)\left(V_{\mathrm{j}} / M_{\mathrm{o}}\right) F_{\mathrm{o}}$ \\
\hline $\mathrm{TR}_{\mathrm{o}}$ & Initial maximum trapping flux $(t=0)$ when all RCs are open \\
\hline $\mathrm{TR}_{\mathrm{o}} / \mathrm{CS}$ & Initial trapping flux per excited cross section; $t=0 ; \mathrm{TR}_{\mathrm{o}} / \mathrm{CS}=\left(F_{\mathrm{v}} / F_{\mathrm{m}}\right)\left(\mathrm{ABS} / \mathrm{CS}_{\mathrm{o}}\right)$ \\
\hline $\mathrm{TR}_{\mathrm{o}} / \mathrm{RC}$ & Initial trapping flux $(t=0)$ when all RCs are open; $\mathrm{TR}_{\mathrm{o}} / \mathrm{RC}=M_{\mathrm{o}}\left(1 / V_{\mathrm{j}}\right)$ \\
\hline
\end{tabular}




\section{RESULTS}

Long-term exposure to different salinities produced some expected physiological changes in Sporobolus pumilus. High soil salinities, for example, resulted in significant alterations in plant-water relations. Stomatal conductance $(g)$ was significantly depressed in $S$. pumilus residing in high soil salinity (30 psu) in comparison to $S$. pumilus in freshwater $(\mathrm{p}=0.009$; Table 2). However, we observed no significant differences in $g$ between moderate salinity (15) and the other 2 salinity levels ( 0 and $30 \mathrm{psu} ; \mathrm{p}>0.095$ ). Prominent differences in leaf water potentials ( $\left.\Psi_{\text {leaf }}\right)$ were observed between the 3 salinity levels $(p=0.004)$, wherein $\Psi_{\text {leaf }}$ declined (more negative) as salinity level increased (Table 2). In this case, $\Psi_{\text {leaf }}$ values were between 2 and 3 times lower in salinity-treated $S$. pumilus $(\mathrm{p}<0.001)$. Prior to heat treatment, tissue water content $(\theta)$ was lower in salt-treated plants than in those receiving only freshwater $(p=0.019)$. Water content in salt-treated plants was typically less than $65 \%$ full turgor, whereas plants receiving freshwater ranged between 72 and $80 \%$ (Table 2; $\mathrm{p}=0.034$ and 0.017 for moderate- and high-salinity treatments in comparison to freshwater). Water content following heat treatment was notably higher $(p<0.001)$ and more variable, with only heat-treated high-salinity plants being significantly lower than freshwater plants $(p=0.048)$. Unlike salinity treatments, the application of heat appeared to have little effect on short-term plant-water relations. In this case, the 60 min heat shock did not significantly alter $g$ or $\Psi_{\text {leaf }}$ in $S$. pumilus regardless of salinity treatment. It is possible that lower stomatal conductance due to dark conditions during heat-treatments resulted in an increase in tissue water content. In this case, tissue water content was significantly different in heat-shocked plants in moderate and high salinities ( $p<0.003$; Table 2$)$. Similarly, control (un-heated) moderate- and high-salinity plants also had elevated tissue water content during the second measurement $(\mathrm{p}<0.001)$.

Both potential quantum yield $\left(F_{\mathrm{v}} / F_{\mathrm{m}}\right)$ and efficiency of energy capture by open PSII RCs $\left(F_{\mathrm{v}}{ }^{\prime} / F_{\mathrm{m}}{ }^{\prime}\right)$ were influenced by soil salinities prior to heat shock $(\mathrm{p}=$ 0.011 and 0.035 , respectively), where $F_{\mathrm{v}}{ }^{\prime} / F_{\mathrm{m}}{ }^{\prime}$ values from 30 psu plants were significantly lower than the other 2 salinities, and $F_{\mathrm{v}} / F_{\mathrm{m}}$ from 30 psu plants was lower than 15 psu (Fig. 1). Prior to treatments, $F_{\mathrm{v}} / F_{\mathrm{m}}$ in plants receiving only freshwater was $0.76 \pm 0.008$ (SE), compared to $0.70 \pm 0.028$ for plants adapted to high salinities (30 psu). The decreases in $F_{\mathrm{v}}{ }^{\prime} / F_{\mathrm{m}}{ }^{\prime}$ were even more pronounced with high soil salinity, where mean values were $0.62 \pm 0.02$ and $0.41 \pm 0.04$ for 0 and 30 salinities, respectively $(\mathrm{p}<0.001)$. While soil salinity influenced both PSII metrics in $S$. pumilus, only $F_{\mathrm{v}} / F_{\mathrm{m}}$ was altered following heat shock $(\mathrm{p}=$ 0.041 and 0.708 for $F_{\mathrm{v}} / F_{\mathrm{m}}$ and $F_{\mathrm{v}}{ }^{\prime} / F_{\mathrm{m}}{ }^{\prime}$, respectively; Fig. 1). In this case, plants receiving freshwater had significant declines in $F_{\mathrm{v}} / F_{\mathrm{m}}$ following heat treatment $(\mathrm{p}=0.017)$. Potential quantum yields in heat-treated $S$. pumilus receiving moderate to high salinities were not significantly different from the un-heated controls $(\mathrm{p}=0.069$ and 0.166 , for 15 and 30 salinity, respectively; Fig. 1). In contrast, perhaps attributed to greater variability within this metric, the chl a fluorescence performance index $\left(P I_{\mathrm{ABS}}\right)$ was apparently not influenced by soil salinity $(p=0.196$; Fig. 1$)$. Moreover, while there was a trend of lower $P I_{\mathrm{ABS}}$ for heat-shocked plants in all salinity groups, again possibly due to higher variability, only $P I_{\mathrm{ABS}}$ for freshwater plants was significantly different $(p=0.014$, 0.405 , and 0.404 for 0,15 , and 30 salinity, respec-

Table 2. Plant-water relation parameters measured on Sporobolus pumilus before (initial) and after heat-shock treatment (post-treatment). Parameters include stomatal conductance $(g)$, leaf-water potential $\left(\Psi_{\text {leaf }}\right)$, and relative water content $(\theta)$ for control and heat-shocked plants pre-acclimated to different salinity treatments $(0,15$, or 30 psu). Statistical relationships within initial or post-heat treatments (i.e. only within a row) are indicated by letters, where values with different letters are considered significantly different. Data are presented as means \pm 1 SE $(n=4 ; \alpha=0.05)$

\begin{tabular}{|c|c|c|c|c|c|c|}
\hline Parameter & 0 psu-Control & 0 psu-Heat & 15 psu-Control & 15 psu-Heat & 30 psu-Control & 30 psu-Heat \\
\hline \multicolumn{7}{|l|}{$g\left(\mu \mathrm{mol} \mathrm{m} \mathrm{m}^{-2} \mathrm{~s}^{-1}\right)$} \\
\hline Initial & $19.5 \pm 0.9^{\mathrm{A}}$ & $27.9 \pm 6.7^{\mathrm{A}}$ & $18.2 \pm 1.2^{\mathrm{AB}}$ & $21.4 \pm 7.9^{\mathrm{AB}}$ & $12.7 \pm 3.2^{\mathrm{B}}$ & $10.0 \pm 0.7^{\mathrm{B}}$ \\
\hline Post-treatment & $15.0 \pm 1.5^{\mathrm{A}}$ & $22.3 \pm 5.7^{\mathrm{A}}$ & $17.1 \pm 2.1^{\mathrm{AB}}$ & $17.9 \pm 2.1^{\mathrm{AB}}$ & $9.3 \pm 1.9^{\mathrm{B}}$ & $10.6 \pm 2.5^{\mathrm{B}}$ \\
\hline \multicolumn{7}{|l|}{$\Psi_{\text {leaf }}(\mathrm{MPa})$} \\
\hline Initial & $-1.6 \pm 0.1^{\mathrm{A}}$ & $-1.5 \pm 0.2^{\mathrm{A}}$ & $-3.2 \pm 0.2^{\mathrm{B}}$ & $-3.0 \pm 0.4^{\mathrm{B}}$ & $-4.4 \pm 0.2^{\mathrm{C}}$ & $-4.6 \pm 0.2^{\mathrm{C}}$ \\
\hline Post-treatment & $-1.6 \pm 0.1^{\mathrm{A}}$ & $-1.6 \pm 0.1^{\mathrm{A}}$ & $-3.1 \pm 0.3^{\mathrm{B}}$ & $-2.9 \pm 0.4^{\mathrm{B}}$ & $-4.2 \pm 0.1^{\mathrm{C}}$ & $-4.5 \pm 0.1^{\mathrm{C}}$ \\
\hline \multicolumn{7}{|l|}{$\theta(\%)$} \\
\hline Initial & $72.9 \pm 0.5^{\mathrm{AB}}$ & $79.1 \pm 2.8^{\mathrm{B}}$ & $61.4 \pm 1.3^{\mathrm{C}}$ & $63.1 \pm 2.7^{C}$ & $60.7 \pm 0.4^{\mathrm{C}}$ & $59.6 \pm 2.3^{C}$ \\
\hline Post-treatment & $86.2 \pm 4.1^{\mathrm{A}}$ & $80.4 \pm 6.3^{\mathrm{A}}$ & $78.3 \pm 4.1^{\mathrm{AB}}$ & $79.3 \pm 4.1^{\mathrm{AB}}$ & $76.6 \pm 6.9^{\mathrm{AB}}$ & $71.7 \pm 2.4^{\mathrm{B}}$ \\
\hline
\end{tabular}



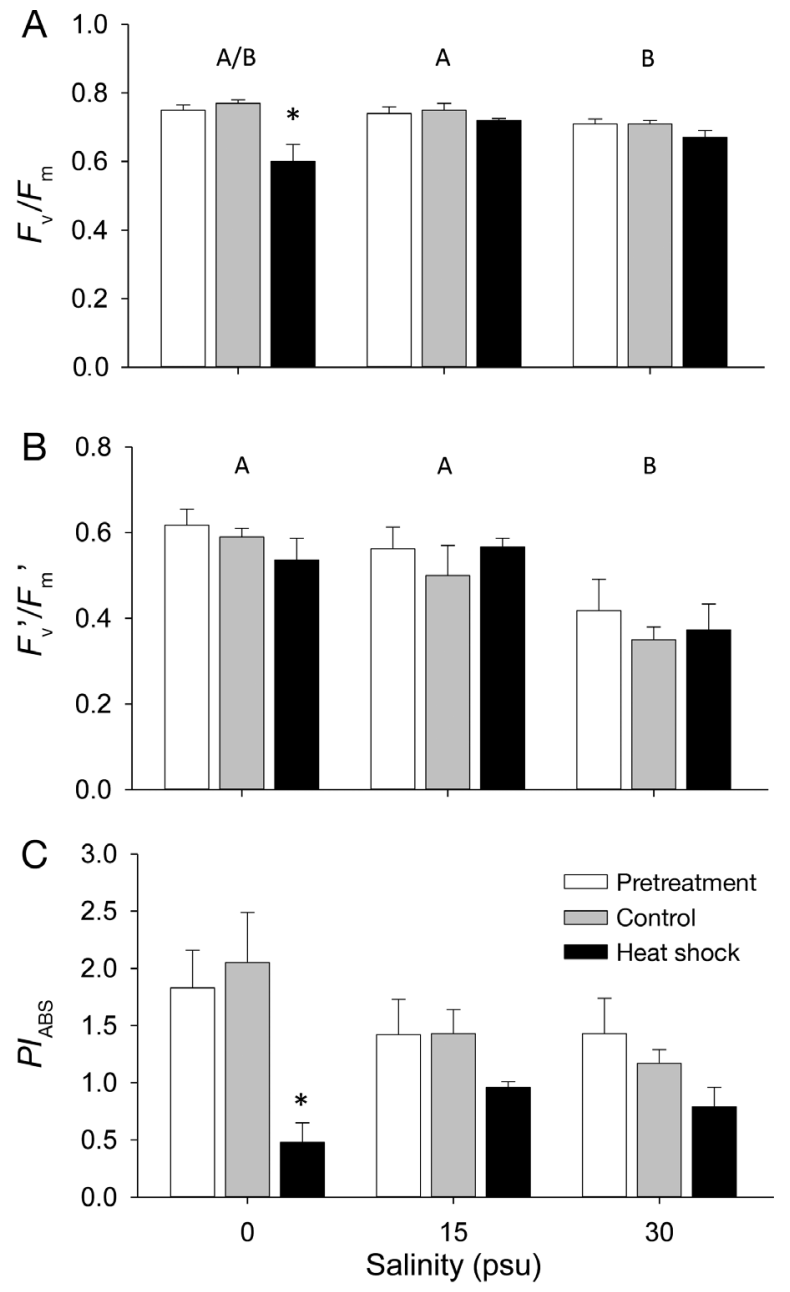

Fig. 1. (A) Potential quantum yield $\left(F_{\mathrm{v}} / F_{\mathrm{m}}\right),(\mathrm{B})$ excitation energy capture efficiency of open reaction centers $\left(F_{\mathrm{v}}{ }^{\prime} / F_{\mathrm{m}}{ }^{\prime}\right)$, and (C) chlorophyll a fluorescence performance index $\left(P I_{\mathrm{ABS}}\right)$ in Sporobolus pumilus before and after heat shock. Measurements were collected on plants pre-acclimated to 3 different salinities $(0,15$, and $30 \mathrm{psu})$ for $18 \mathrm{mo}$. Pretreatment measurements (white bars) were recorded in all plants prior to heat shock. Control plants (gray bars) were exposed to ambient temperatures in darkness, and heat-shocked plants (black bars) were exposed to $45^{\circ} \mathrm{C}$ for $60 \mathrm{~min}$ in darkness. Data are presented as means \pm SE. Significant differences associated with salinity are indicated by different letters above treatment groups ( 3 bars) and differences from pretreatment within each salinity level are indicated by asterisks $(\mathrm{n}=4 ; \alpha=0.05)$

tively). That is, only $S$. pumilus residing in freshwater had significantly lower $P I_{\mathrm{ABS}}$ (compared to pre-treatment and control groups) following heat shock.

Polyphasic chl a fluorescence transients (OJIP) reveal distinct phases in fluorescence rise from $\mathrm{O}$ to $\mathrm{P}$ (Fig. 2). The O-step is the minimum fluorescence when $Q_{\mathrm{A}}$ (primary electron acceptor) is oxidized, and the P-step is the fluorescence when $Q_{\mathrm{A}}$ is fully reduced (Strasser \& Srivastava 1995, Kalaji et al.

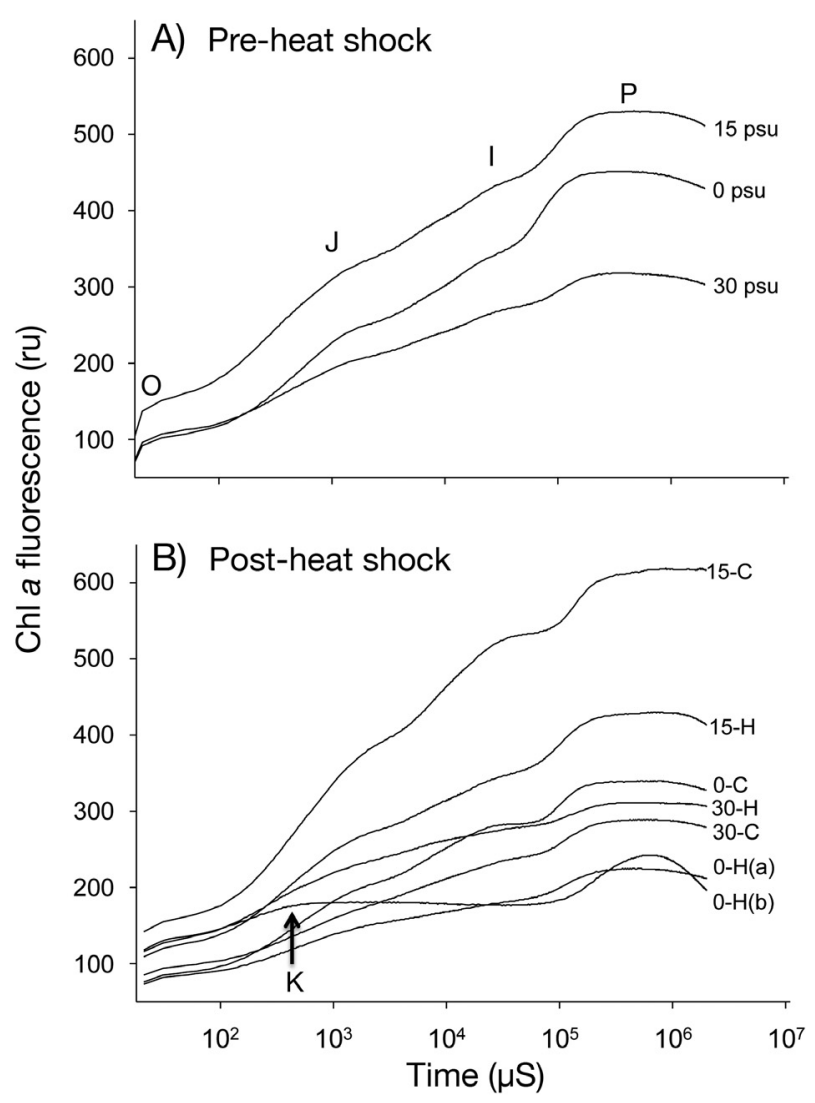

Fig. 2. Typical chlorophyll a fluorescence transients (OJIP) for Sporobolus pumilus (A) prior to heat treatment and (B) following heat treatment. Salinity treatments $(0,15$, and $30 \mathrm{psu})$ are indicated by numbers following each transient, and letters in the post-heat treatment (Panel B) indicate control (C), heat treatment $(\mathrm{H})$, or 2 different responses observed in heat-treated plants acclimated to freshwater $(0-\mathrm{H}(\mathrm{a})$ and 0 $\mathrm{H}(\mathrm{b})$ ). Note the presence of a K-step (for the $0-\mathrm{H}(\mathrm{b})$ transient; panel B) was observed in approximately $25 \%$ of heattreated plants that were pre-acclimated to freshwater. Values are expressed as relative units (ru)

2014). The intermediate rise, from $J$ to $I$, is thought to reflect the successive reduction of intersystem electron carriers (i.e. $Q_{\mathrm{B}}$, plastoquinone, cytochrome, and plastocyanin; Strasser et al. 2004, Yusuf et al. 2010, Chen et al. 2016). During heat stress, typically around $45^{\circ} \mathrm{C}$ or above, the J- and I-steps can be altered or replaced with a single K-step that typically begins at or around $300 \mu$ s (Strasser et al. 2004, Chen et al. 2016). In this study, K-steps with a concomitant loss of J- and I-steps were observed in approximately $25 \%$ of the heat-treated S. pumilus that were preacclimated to freshwater (Fig. 2). Interestingly, no Kstep was observed in any heat-treated plants previously acclimated to moderate- or high-salinity conditions. Moreover, there were no significant changes in any polyphasic fluorescence transient 
parameters observed between the control and heattreated $S$. pumilus residing in moderate salinity (15 psu). In contrast, changes in OJIP parameters were apparent in plants exposed to freshwater (0 psu) or high (30 psu) salinity treatments. For these treatments, salinity significantly influenced maximum fluorescence $\left(F_{\mathrm{m}}\right)$, whereby lower salinities reported higher values $(\mathrm{p}=0.027)$.

Heat treatments resulted in profound changes in OJIP parameters, especially in plants residing in freshwater (Fig. 3). For example, heat shock resulted in significant increases in the proportion of closed RCs at the J-step $\left(V_{\mathrm{j}} ; \mathrm{p}=0.001\right.$; Table 3$)$. More specif- ically, $V_{\mathrm{j}}$ increased by 22 and $11 \%$ in 0 and 30 salinity treated plants, respectively. Heat stress also resulted in a significant reduction in $Q_{\mathrm{A}}$ reoxidation rate, as suggested by 83 and $18 \%$ increases in $M_{\mathrm{o}}$ for 0 and 30 psu treated plants, respectively $(p=0.001$; Table 3). Heat-treated $S$. pumilus residing in freshwater also had a $129 \%$ increase in absorption flux per $\mathrm{RC}$ (ABS/RC) and a 50\% increase in trapping flux per $\mathrm{RC}\left(\mathrm{TR}_{\mathrm{o}} / \mathrm{RC} ; \mathrm{p}=0.009\right.$ and 0.006 , respectively) in comparison to unheated freshwater controls (Fig. 3). Heat-treated plants in freshwater also had a $48 \%$ decrease in maximum potential for primary photochemistry $\left(F_{\mathrm{v}} / F_{\mathrm{o}} ; \mathrm{p}<0.001\right)$, a $47 \%$ decrease in elec-
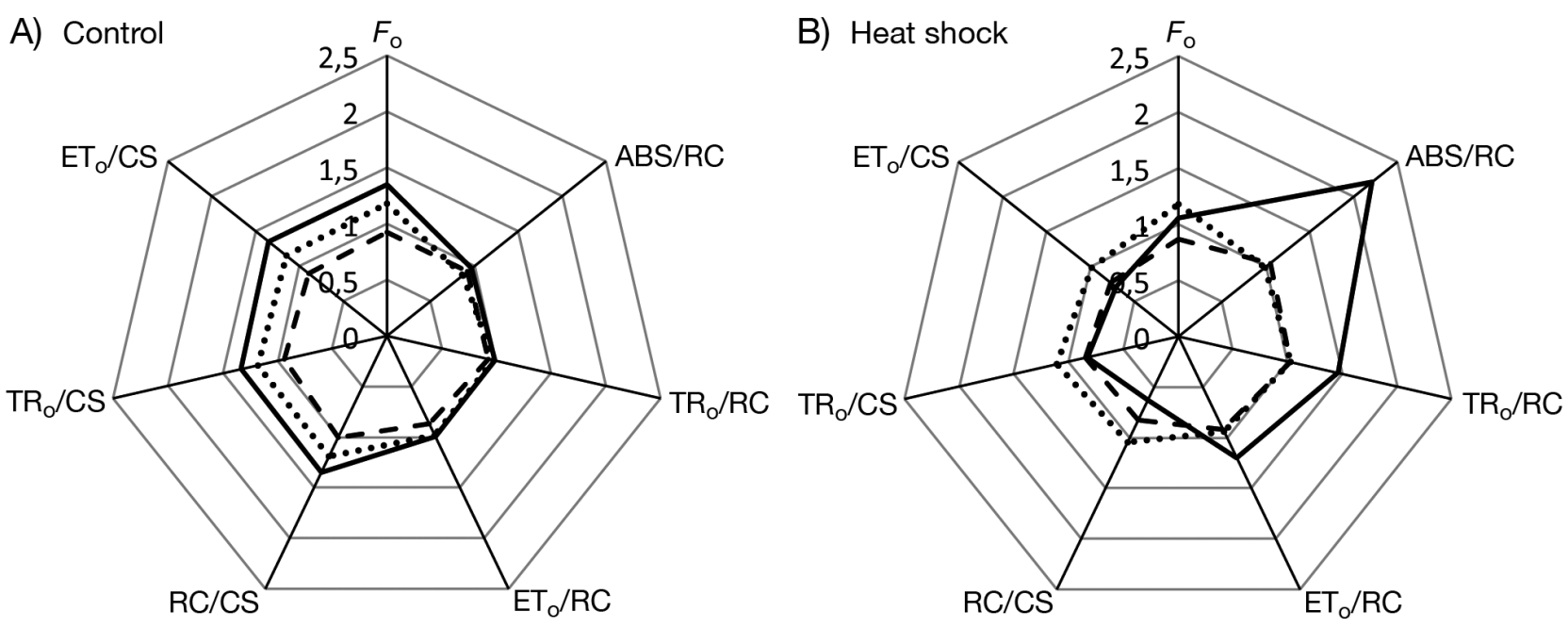

C) Control

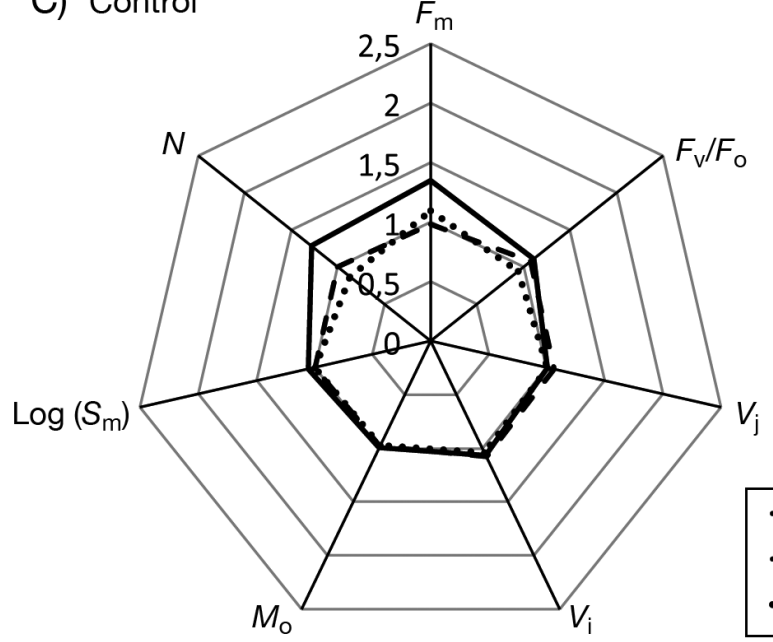

D) Heat shock

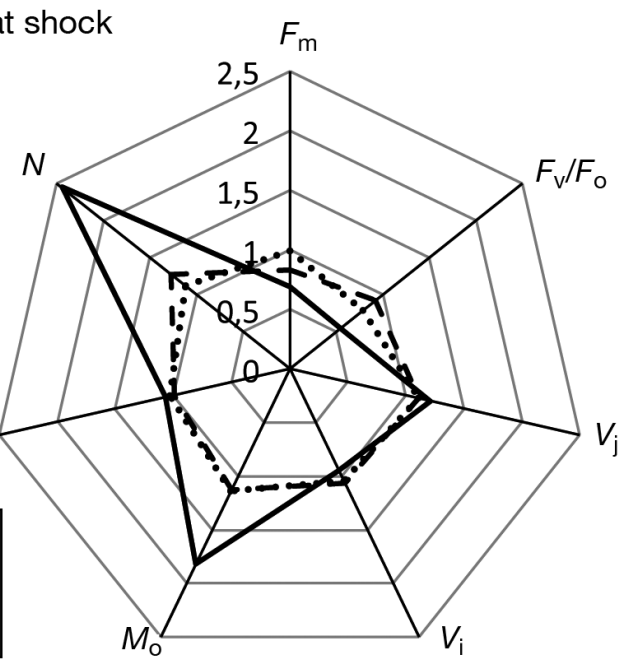

Fig. 3. Spider plots of selective chlorophyll a fluorescent induction transient parameters measured in $(A, C)$ control and $(B, D)$ heat-shocked Sporobolus pumilus. These parameters help characterize the behavior of Photosystem II following heat shock in plants pre-acclimated to 3 different salinities: 0 (solid lines), 15 (dashed lines), and 30 psu (dotted lines). Parameters were calculated from fluorescent transients, wherein the presented values were normalized as a relative proportion of the initial (pre-heat shock) measurements (e.g. a doubling of a particular response would have a value of 2). Definitions of fluorescent parameters used in these plots can be found in Table 1 
Table 3. Chlorophyll a fluorescent output parameters recorded following heat-shock treatments on Sporobolus pumilus acclimated to different salinities $(0,15$, and $30 \mathrm{psu})$. Statistical differences between control and heat treatments within each salinity class are indicated by asterisks. Data are presented as means $\pm 1 \mathrm{SE}(\mathrm{n}=4 ; \alpha=0.05)$. Definitions and mathematical expressions of each fluorescent output parameter reported can be found in Table 1

\begin{tabular}{|lcccccc|}
\hline Parameter & 0 psu-Control & 0 psu-Heat & 15 psu-Control & 15 psu-Heat & 30 psu-Control & 30 psu-Heat \\
\hline$F_{\mathrm{o}}$ & $118.5 \pm 7.5$ & $92.7 \pm 10.5$ & $119.3 \pm 6.4$ & $112.0 \pm 7.9$ & $103.5 \pm 13.1$ & $103.8 \pm 7.9$ \\
$F_{\mathrm{m}}$ & $528 \pm 27$ & $268 \pm 42^{*}$ & $507 \pm 47$ & $427 \pm 30$ & $364 \pm 51$ & $328 \pm 35$ \\
$F_{\mathrm{v}} / F_{\mathrm{o}}$ & $3.5 \pm 0.32$ & $1.8 \pm 0.32^{*}$ & $3.2 \pm 0.30$ & $2.7 \pm 0.08$ & $2.5 \pm 0.17$ & $2.1 \pm 0.24$ \\
$V_{\mathrm{j}}$ & $0.46 \pm 0.01$ & $0.56 \pm 0.02^{*}$ & $0.51 \pm 0.01$ & $0.52 \pm 0.01$ & $0.46 \pm 0.006$ & $0.51 \pm 0.02^{*}$ \\
$V_{\mathrm{i}}$ & $0.78 \pm 0.01$ & $0.69 \pm 0.06$ & $0.81 \pm 0.01$ & $0.79 \pm 0.01$ & $0.76 \pm 0.01$ & $0.76 \pm 0.02$ \\
$M_{\mathrm{o}}$ & $0.78 \pm 0.06$ & $1.43 \pm 0.26^{*}$ & $0.89 \pm 0.03$ & $1.02 \pm 0.03$ & $0.85 \pm 0.01$ & $1.00 \pm 0.06^{*}$ \\
$\mathrm{Log} S_{\mathrm{m}}$ & $2.76 \pm 0.01$ & $2.72 \pm 0.11$ & $2.75 \pm 0.09$ & $2.84 \pm 0.03$ & $2.73 \pm 0.04$ & $2.83 \pm 0.03$ \\
$N$ & $892 \pm 67$ & $1706 \pm 782$ & $1074 \pm 233$ & $1379 \pm 135$ & $1044 \pm 99$ & $1345 \pm 99$ \\
$\mathrm{ABS} / \mathrm{RC}$ & $2.16 \pm 0.15$ & $4.95 \pm 1.29^{*}$ & $2.34 \pm 0.14$ & $2.67 \pm 0.09$ & $2.54 \pm 0.04$ & $2.90 \pm 0.14$ \\
$\mathrm{TR} / \mathrm{RC}$ & $1.66 \pm 0.07$ & $2.49 \pm 0.38^{*}$ & $1.75 \pm 0.04$ & $1.94 \pm 0.05$ & $1.81 \pm 0.01$ & $1.92 \pm 0.04$ \\
$\mathrm{ET} / \mathrm{RC}$ & $0.88 \pm 0.02$ & $1.06 \pm 0.13$ & $0.86 \pm 0.03$ & $0.91 \pm 0.04$ & $0.96 \pm 0.01$ & $0.92 \pm 0.02$ \\
$\mathrm{ET} / \mathrm{CS}$ & $48.5 \pm 2.0$ & $25.5 \pm 5.2^{*}$ & $44.8 \pm 4.3$ & $38.5 \pm 2.4$ & $39.2 \pm 5.0$ & $33.5 \pm 3.0$ \\
$\mathrm{RC} / \mathrm{CS}$ & $54.9 \pm 2.9$ & $25.5 \pm 7.0^{*}$ & $51.2 \pm 3.8$ & $41.9 \pm 2.1$ & $40.8 \pm 5.6$ & $35.9 \pm 2.8$ \\
$\mathrm{TR}_{\mathrm{o}} / \mathrm{CS}$ & $91.4 \pm 4.7$ & $56.9 \pm 9.2$ & $90.2 \pm 6.3$ & $81.7 \pm 5.7$ & $74.0 \pm 9.7$ & $69.5 \pm 5.8$ \\
\hline
\end{tabular}

tron transport flux per excited cross section $\left(\mathrm{ET}_{0} / \mathrm{CS}_{\text {; }}\right.$ $\mathrm{p}<0.001)$, and a $54 \%$ decrease in the density of $Q_{\mathrm{A}}$ reducing PSII RCs (RC/CS; $\mathrm{p}<0.001$; Fig. 3). It is important to note that changes in $\mathrm{ABS} / \mathrm{RC}, \mathrm{TR}_{0} / \mathrm{RC}$, $F_{\mathrm{v}} / F_{\mathrm{o}}, \mathrm{ET}_{\mathrm{o}} / \mathrm{CS}$, and RC/CS were not observed in heattreated $S$. pumilus receiving salinity treatments (i.e. 15 and $30 \mathrm{psu}$; Table 3).

\section{DISCUSSION}

As expected, salinity treatments promoted notable changes in plant-water relations for Sporobolus pumilus. Specifically, there were declines in $g$, $\Psi_{\text {leaf }}$ and $\theta$ as salinity increased from 0 to 30 psu. Similar salinity-associated responses have been reported in other studies (Khan et al. 2000, Salpeter et al. 2012), and were attributed to lower soil-water potentials $\left(\Psi_{\text {soil }}\right)$ fostered by high solute levels within interstitial pore-waters (Salpeter et al. 2012). That is, plants must maintain a gradient of decreasing water potentials to achieve water flux through the soil-plantatmosphere continuum. Water potential $(\Psi)$ of pure water is designated at $0 \mathrm{MPa}$, and any addition of salts or other solutes will effectively lower $\Psi$. In the absence of any physiological modifications, an increase in soil solutes would lower $\Psi_{\text {soil }}$ and osmotically withhold water from plant roots (Larcher 2003, Touchette et al. 2009b, Salpeter et al. 2012). Therefore, to promote water influx and positive turgor pressure, plants may lower $\Psi$ within developing and/ or existing tissue by increasing internal solute concentrations (Pezeshki \& DeLaune 1993, Flowers \&
Colmer 2008, Hessini et al. 2008). In S. pumilus, these physiological adjustments following sudden increases in salinity (including lower $g, \Psi_{\text {leaf }}$ and $\theta$ ) may take several weeks to fully develop (Salpeter et al. 2012). Therefore, extending pre-acclimation in some halophytes may be necessary to capture long-term physiological modifications to higher salinities.

In some areas, coastal marsh systems must contend with unusually high summer temperatures. In Salicornia-Distichlis marshes, for example, sediment surface temperatures can reach $45^{\circ} \mathrm{C}$ (Teal 1958). Similarly, surface temperature measurements using Littoraria irrorata biomimic sensors attached to Sporobolus alterniflorus (syn. Spartina alterniflora) stalks revealed temperatures exceeding $45^{\circ} \mathrm{C}$ (Iacarella \& Helmuth 2011). High temperatures can adversely affect a number of cellular and metabolic processes in plants (e.g. loss of membrane stability, enzyme inactivation, inhibition of protein synthesis; Wahid et al. 2007). Photosynthesis is particularly vulnerable to elevated temperature stress, as high temperatures can promote a range of physiological perturbations such as inhibition within the oxygen-evolving complex, disruption of electron transport reactions, and diminished PSII photochemical efficiencies (Chen et al. 2016, Stirbet et al. 2018). Potential quantum yield $\left(F_{\mathrm{v}} / F_{\mathrm{m}}\right)$ is widely used as an indicator of PSII function and reflects the trapping efficiency of absorbed light to reduce the primary electron acceptor, $Q_{\mathrm{A}}$ (Li et al. 2009). Often, declining $F_{\mathrm{v}} / F_{\mathrm{m}}$ values represent some form of PSII damage or photoinhibition during environmental stress (Baker 2008, Ogaya et al. 2011). In this study, high salinity (30 psu) resulted in a small, 
but significant, decline in $F_{\mathrm{v}} / F_{\mathrm{m}}$ for $S$. pumilus (when compared to non-heat-treated plants residing in freshwater and moderate salinities). This response is consistent with other studies wherein elevated salinities fostered $F_{\mathrm{v}} / F_{\mathrm{m}}$ declines in photosynthetic tissues, including the macroalga Ulva lactuca, and coastal graminoids Phragmites australis and Juncus roemerianus (Xia et al. 2004, Deng et al. 2011, Touchette et al. 2012). Interestingly, heat shock also resulted in a significant $F_{\mathrm{v}} / F_{\mathrm{m}}$ decrease in this study, but this phenomenon was only observed in $S$. pumilus acclimated to freshwater. In contrast, the excitation capture efficiency of open PSII RCs, $F_{\mathrm{v}}{ }^{\prime} / F_{\mathrm{m}}{ }^{\prime}$, was not affected by heat treatments.

Some studies have shown that $F_{\mathrm{v}} / F_{\mathrm{m}}$ is not always sensitive to heat stress, and others have expressed concern that this parameter lacks specific details regarding alterations within PSII behavior (Strasser et al. 2000, Crafts-Brandner \& Salvucci 2002, Wen et al. 2005). The fluorescent marker $P I_{\mathrm{ABS}}$ offers a broader evaluation of PSII performance by considering processes related to active RC densities, primary photochemistry, and electron transport (Strasser et al. 2000, Stirbet et al. 2018). $P I_{\mathrm{ABS}}$, therefore, is responsive to changes in antenna properties, trapping efficiencies, and electron transport beyond $Q_{\mathrm{A}}$ (Kalaji et al. 2014). In this study, there was no salinity-induced response for $P I_{\mathrm{ABS}}$, although high variability within this parameter may, in part, contribute to a lack of statistical difference. Nevertheless, $P I_{\mathrm{ABS}}$ did decline in heat-treated plants that were previously acclimated to freshwater. Heat-stress-induced declines in $P I_{\mathrm{ABS}}$, as with $F_{\mathrm{v}} / F_{\mathrm{m}}$, were not observed in salinityacclimated plants, suggesting that $S$. pumilus preacclimated to environmental salts may have greater PSII thermostability compared to plants residing in strictly freshwater. Similar physiological responses, where exogenously supplied salts (e.g. $\mathrm{NaCl}$ or $\mathrm{CaCl}_{2}$ ) promoted PSII thermostability, were observed in other species including Artemisia anethifolia, Nicotiana tabacum, Sorghum bicolor, and Suaeda salsa (Lu \& Zhang 1998, Lu et al. 2003, Wen et al. 2005, Tan et al. 2011, Yan et al. 2012). Moreover, studies have shown that low osmotic potentials (often attributed to low water stress) within leaf tissues are also correlated with PSII stability during heat stress (Seemann et al. 1986, Havaux 1992). Yan et al. (2012) suggested that the accumulation of osmoprotectant(s) (e.g. glycinebetaine or proline), could possibly contribute to enhanced thermoresistance in plants exposed to osmotic stressors (salt or drought), as these compounds tend to stabilize subcellular structures, control free radical accumulation, and buffer cellular redox potentials (Lu et al. 2003, Ashraf \& Foolad 2007).

Closer inspection of polyphasic fast chl a fluorescent kinetics, as derived from OJIP transients, can provide some insight into possible physiological mechanisms that promote $P I_{\mathrm{ABS}}$ and $F_{\mathrm{v}} / F_{\mathrm{m}}$ declines in heat-treated plants grown in freshwater. The initial slope $\left(M_{0}\right)$ and the variable fluorescence at the J-step $\left(V_{\mathrm{j}}\right)$ are useful in calculating the trapping flux (TR) per active PSII RC $\left(\mathrm{TR}_{\mathrm{o}} / \mathrm{RC}=M_{\mathrm{o}} / V_{\mathrm{j} \text {; }}\right.$ Stirbet et al. 2018). Using these metrics, $T_{0} / R C$ reflects the maximal rate of RC closures across all RCs that can functionally close (Wen et al. 2005). During stress conditions, it is possible that some RCs no longer close and, instead, serve as heat sinks or 'silent RCs' that do not reduce $Q_{\mathrm{A}}$ to $Q_{\mathrm{A}}{ }^{-}$(Strasser et al. 2004). Thus, $\mathrm{TR}_{\mathrm{o}} / \mathrm{RC}$ only refers to RCs that are photochemically active and can reduce $Q_{\mathrm{A}}$. In this study, increases in $\mathrm{TR}_{0} / \mathrm{RC}$ (observed in heat-treated freshwater plants), likely indicate inactivation of PSII RCs and/or a decrease in re-oxidation rates of $Q_{\mathrm{A}}$ (Wen et al. 2005). Inactivation of RCs, however, is further supported by lower active PSII RC densities (i.e. lower RC/CS) observed in heat-treated plants acclimated to freshwater. Interestingly, the number of active RCs was considerably lower in heat-treated plants acclimated to freshwater only, suggesting that salt exposure for plants in the other treatments offers some level of thermoprotection of PSII with improved RC thermostability. Chl a fluorescent transients in heattreated freshwater plants also revealed a K-step in approximately $25 \%$ of the plants. The K-step is well documented in heat-stress studies involving plants, and is thought to be attributable to disruptions in the donor side of PSII, especially the destruction of the oxygen-evolving complex through a dissociation of the manganese cluster (Chen et al. 2016, Stirbet et al. 2018). The lack of an observed K-step in salt-acclimated plants following heat-shock also demonstrates enhanced thermotolerance of PSII, and suggests that exposure to environmental salts may also improve the thermostability of the oxygen-evolving complex (Mathur et al. 2013).

Plant physiological behavior associated with simultaneous multiple stressors can be difficult to predict due to the often complex nature of their responses. Such responses may either be reinforcing or offsetting (Aber et al. 2001). In this study, the presence of salt promoted some degree of salt stress in S. pumilus as indicated by changes in plant-water relations and quantum yield. Similarly, high-temperature shock alone also promoted plant stress as indicated by lower $P I_{\mathrm{ABS}}, F_{\mathrm{m}}$, and $F_{\mathrm{v}} / F_{\mathrm{o}}$, and higher $V_{\mathrm{j}}, M_{\mathrm{o}}$, and $\mathrm{TR}_{\mathrm{o}} / \mathrm{RC}$. 
While it may seem intuitive that the combined stressors, involving disruptions in both plant-water relations and PSII, would foster additive responses compromising the overall ability of a plant to survive, this was not observed in S. pumilus. Indeed, the presence of environmental salts appeared to offset the expected heat-related responses, allowing these halophytes to seemingly tolerate unusually high temperatures. More specifically, it would appear that saline porewaters increased the resistance of PSII to heat stress by minimizing initial disturbances within the PSII RCs and subsequent disruptions within the oxygen-evolving complex. Similar responses have been observed in the halophyte $S$. salsa found in northern China, where it is adapted to high-saline soils with summer temperatures approaching $45^{\circ} \mathrm{C}$ ( $\mathrm{Lu}$ et al. 2003). While specific mechanisms that promote greater thermotolerance in plants exposed to environmental salts are unclear, it is possible that compatible solute accumulations (e.g. betaines, proline, and sugar alcohols) in plants experiencing osmotic stress (e.g. saline systems or drought) may foster some protective benefits to PSII processes. Glycinebetaine, for example, has been shown to stabilize the oxygen-evolving complex and protect the PSII core from heat stress (Papageorgiou \& Murata 1995, Allakhverdiev et al. 2003, Yang et al. 2007). This compound has also been shown to accumulate in chloroplasts during periods of osmotic stress (Robinson \& Jones 1986). Regardless of the physiological mechanisms involved in promoting thermotolerance in $S$. pumilus, such responses would likely play a role in species occurrence and distribution, especially as global temperatures rise (Touchette et al. 2019). That is, $S$. pumilus also occurs in coastal freshwater systems (e.g. dune swales) that lack any direct exposure to seawater. It is conceivable that these freshwater populations will be more vulnerable to rising global temperatures relative to their counterparts residing in saline-rich salt marshes.

Acknowledgements. Support for this study was generously provided by the North Carolina Sea Grant (NCSG), UNC Water Resources Research Institute (WRRI), US Geological Society, and Elon University Department of Biological Science. We thank 2 anonymous reviewers for their comments and insights that helped strengthen the final manuscript.

\section{LITERATURE CITED}

Aber J, Neilson RP, McNulty S, Lenihan JM, Bachelet D, Drapek RJ (2001) Forest processes and global environmental change: predicting the effects of individual and multiple stressors. BioScience 51:735-751

Adams DA (1963) Factors influencing vascular plant zona- tion in North Carolina salt marshes. Ecology 44:445-456

Allakhverdiev SI, Hayashi H, Nishiyama Y, Ivanov AG and others (2003) Glycinebetaine protects the D1/D2/Cytb559 complex of photosystem II against photo-induced and heat-induced inactivation. J Plant Physiol 160:41-49

Ashraf M, Foolad M (2007) Roles of glycine betaine and proline in improving plant abiotic stress resistance. Environ Exp Bot 59:206-216

Baker NR (2008) Chlorophyll fluorescence: a probe of photosynthesis in vivo. Annu Rev Plant Biol 59:89-113

Barbour MG, Davis CB (1970) Salt tolerance of five California salt marsh plants. Am Midl Nat 84:262-265

*Barrs HD, Weatherley PE (1962) A re-examination of the relative turgidity technique of estimating water deficit in leaves. Aust J Biol Sci 15:413-428

* Bertness MD (1991) Zonation of Spartina patens and Spartina alterniflora in a New England salt marsh. Ecology 72: 138-148

Butzeck C, Eschenbach A, Gröngröft A, Hansen K, Nolte S, Jensen K (2015) Sediment deposition and accretion rates in tidal marshes are highly variable along estuarine salinity and flooding gradients. Estuaries Coasts 38:434-450

Cavender-Bares J, Bazzaz FA (2004) From leaves to ecosystems: using chlorophyll fluorescence to assess photosynthesis and plant function in ecological studies. In: Papageorgiou GC, Govindjee (eds) Chlorophyll fluorescence: a signature of photosynthesis. Kluwer Academic Publishers, Dordrecht, p 737-755

Chen S, Yang J, Zhang M, Strasser RJ, Qiang S (2016) Classification and characteristics of heat tolerance in Ageratina adenophora populations using fast chlorophyll a fluorescence rise O-J-I-P. Environ Exp Bot 122:126-140

Crafts-Brandner SJ, Salvucci ME (2002) Sensitivity of photosynthesis in a $\mathrm{C} 4$ plant, maize, to heat stress. Plant Physiol 129:1773-1780

* Curtis PS, Drake BG, Leadley PW, Arp WJ, Whigham DF (1989) Growth and senescence in plant communities exposed to elevated $\mathrm{CO}_{2}$ concentrations on an estuarine marsh. Oecologia 78:20-26

*Dąbrowski P, Baczewska AH, Pawluśkiewicz B, Paunov M, Alexantrov V, Goltsev V, Kalaji MH (2016) Prompt chlorophyll a fluorescence as a rapid tool for diagnostic changes in PSII structure inhibited by salt stress in perennial ryegrass. J Photochem Photobiol B 157:22-31

Deng C, Zhang G, Pan X (2011) Photosynthetic responses in reed (Phragmites australis (CAV.) TRIN. ex Steud.) seedlings induced by different salinity-alkalinity and nitrogen levels. J Agric Sci Technol 13:687-699

Drake BG (1989) Photosynthesis of salt marsh species. Aquat Bot 34:167-180

* Flowers TJ, Colmer TD (2008) Salinity tolerance in halophytes. New Phytol 179:945-963

*Havaux M (1992) Stress tolerance of photosystem II in vivo: antagonistic effects of water, heat, and photoinhibition stresses. Plant Physiol 100:424-432

*Hessini K, Ghandour M, Albouchi A, Soltani A, Werner KH, Abdelly C (2008) Biomass production, photosynthesis, and leaf water relations of Spartina alterniflora under moderate water stress. J Plant Res 121:311-318

*Hester MW, Mendelssohn IA, McKee KL (1996) Intraspecific variation in salt tolerance and morphology in the coastal grass Spartina patens (Poaceae). Am J Bot 83: 1521-1527

Iacarella JC, Helmuth B (2011) Experiencing the salt marsh environment through the foot of Littoraria irrorate: be- 
havioral responses to thermal and desiccation stress. J Exp Mar Biol Ecol 409:143-153

Joly RJ (1985) Techniques for determining seedling water status and their effectiveness in assessing stress. In: Duryea ML (ed) Evaluating seedling quality: principles, procedures, and predictive abilities of major tests. Forest Research Laboratory, Oregon State University, Corvallis, OR, p 17-28

Kalaji HM, Jajoo A, Oukarroum A, Brestic M and others (2014) The use of chlorophyll fluorescence kinetics analysis to study the performance of photosynthetic machinery in plants. In: Ahmad P, Rasool S (eds) Emerging technologies and management of crop stress tolerance, Vol 2. Academic Press, San Diego, CA, NY, p 347-384

Kalaji HM, Račková L, Paganová V, Swoczyna T, Rusinowski S, Sitko K (2018) Can chlorophyll-a fluorescence parameters be used as bio-indicators to distinguish between drought and salinity stress in Tilia cordata Mill? Environ Exp Bot 152:149-157

Khan MA, Ungar IA, Showalter AM (2000) Effects of salinity on growth, water relations and ion accumulation of the subtropical perennial halophyte, Atriplex griffithii var. stocksii. Ann Bot (Lond) 85:225-232

Larcher W (2003) Physiological plant ecology: ecophysiology and stress physiology of functional groups. SpringerVerlag, Berlin

* Li P, Cheng L, Gao H, Jiang C, Peng T (2009) Heterogeneous behavior of PSII in soybean (Glycine max) leaves with identical PSII photochemistry efficiency under different high temperature treatments. J Plant Physiol 166: 1607-1615

* Li SH, Ge ZM, Xie LN, Chen W and others (2018) Ecophysiological response of native and exotic salt marsh vegetation to waterlogging and salinity: implications for the effects of sea-level rise. Sci Rep 8:2441

$\mathrm{Lu}$ C, Zhang J (1998) Thermostability of photosystem II is increased in salt-stressed sorghum. Funct Plant Biol 25: 317-324

Lu C, Zhang J (2000) Heat-induced multiple effects on PSII in wheat plants. J Plant Physiol 156:259-265

K Lu C, Jiang G, Wang B, Kuang T (2003) Photosystem II photochemistry and photosynthetic pigment composition in salt-adapted halophyte Artimisia anethifolia grown under outdoor conditions. J Plant Physiol 160:403-408

* Mathur S, Mehta P, Jajoo A (2013) Effects of dual stress (high salt and high temperature) on the photochemical efficiency of wheat leaves (Triticum aestivum). Physiol Mol Biol Plants 19:179-188

Mittler R, Finka A, Goloubinoff P (2012) How do plants feel the heat? Trends Biochem Sci 37:118-125

Noe GB, Zedler JB (2000) Differential effects of four abiotic factors on the germination of salt marsh annuals. Am J Bot 87:1679-1692

Ogaya R, Penuelas J, Asensio D, Llusià J (2011) Chlorophyll fluorescence responses to temperature and water availability in two co-dominant Mediterranean shrub and tree species in a long-term field experiment simulating climate change. Environ Exp Bot 73:89-93

Osmond CB, Austin MP, Berry JA, Billings WD and others (1987) Stress physiology and the distribution of plants. BioScience 37:38-48

Papageorgiou GC, Murata N (1995) The unusually strong stabilizing effects of glycine betaine on the structure and function of the oxygen-evolving photosystem II complex. Photosynth Res 44:243-252
Partridge TR, Wilson JB (1987) Salt tolerance of salt marsh plants of Otago, New Zealand. N Z J Bot 25:559-566

Pearcy RW, Ustin SL (1984) Effects of salinity on growth and photosynthesis of three California tidal marsh species. Oecologia 62:68-73

Pennings SC, Grant MB, Bertness MD (2005) Plant zonation in low-latitude salt marshes: disentangling the roles of flooding, salinity, and competition. J Ecol 93:159-167

Peterson PM, Romaschenko K, Arrieta YH, Saarela JM (2014) A molecular phylogeny and new subgeneric classification of Sporobolus (Poaceae: Chloridoideae: Sporobolinae). Taxon 63:1212-1243

Pezeshki SR, DeLaune RD (1993) Effects of soil hypoxia and salinity on gas exchange and growth of Spartina patens. Mar Ecol Prog Ser 96:75-81

* Queitsch C, Hong SW, Vierling E, Lindquist S (2000) Heat shock protein 101 plays a crucial role in thermotolerance in Arabidopsis. Plant Cell 12:479-492

Ranwell DS (1972) Ecology of salt marshes and sand dunes. Chapman and Hall Ltd., London

* Robinson SP, Jones GP (1986) Accumulation of glycinebetaine in chloroplasts provides osmotic adjustment during salt stress. Funct Plant Biol 13:659-668

Rozema J, Bijwaard P, Prast G, Broekman R (1985) Ecophysiological adaptations of coastal halophytes from foredunes and salt marshes. Vegetatio 62:499-521

* Salpeter KE, Millemann DR, Caputo MF, White BL, Touchette BW (2012) Delayed modifications in plantwater relations in the coastal marsh halophyte Spartina patens following sudden increases in soil salinity. Bot Mar 55:307-310

* Scholander PF, Hammel HT, Bradstreet ED, Hemmingsen EA (1965) Sap pressure in vascular plants. Science 148: 339-346

Schröder HK, Kiehl K, Stock M (2002) Directional and nondirectional vegetation changes in a temperate salt marsh in relation to biotic and abiotic factors. Appl Veg Sci 5:33-44

Seemann JR, Downton WJS, Berry JA (1986) Temperature and leaf osmotic potential as factors in the acclimation of photosynthesis to high temperature in desert plants. Plant Physiol 80:926-930

SPSS (2011) IBM SPSS statistics for Windows, version 20.0. IBM Corp, New York, NY

Stirbet A, Lazár D, Kromdijk J (2018) Chlorophyll a fluorescence induction: Can just a one-second measurement be used to quantify abiotic stress responses? Photosynthetica 56:86-104

* Strasser RJ, Srivastava A (1995) Polyphasic chlorophyll a fluorescence transients in plants and cyanobacteria. Photochem Photobiol 61:32-42

Strasser RJ, Srivastava A, Tsimilli-Michael M (2000) The fluorescence transient as a tool to characterize and screen photosynthetic samples. In: Yunus M, Pathre U, Mohanty P (eds) Probing photosynthesis: mechanisms, regulation and adaptation. Taylor and Francis, London, p 445-483

Strasser RJ, Tsimilli-Michael M, Srivastava A (2004) Analysis of the chlorophyll a fluorescence transient. In: Papageorgiou GC, Govindjee (eds) Chlorophyll fluorescence: a signature of photosynthesis. Kluwer Academic Publishers Press, Dordrecht, p 321-362

Tan W, Meng QW, Brestic M, Olsovska K, Yang X (2011) Photosynthesis is improved by exogenous calcium in heatstressed tobacco plants. J Plant Physiol 168:2063-2071

* Teal JM (1958) Distribution of fiddler crabs in Georgia salt marshes. Ecology 39:185-193 
Thach LB, Shapcott A, Schmidt S, Critchley C (2007) The OJIP fast fluorescence rise characterizes Graptophyllum species and their stress responses. Photosynth Res 94: 423-436

Touchette BW (2006) Salt tolerance in a Juncus roemerianus brackish marsh: spatial variations in plant water relations. J Exp Mar Biol Ecol 337:1-12

Touchette BW (2007) Seagrass-salinity interactions: physiological mechanisms used by submersed marine angiosperms for a life at sea. J Exp Mar Biol Ecol 350:194-215

Touchette BW, Rhodes KL, Smith GA, Poole M (2009a) Salt spray induces osmotic adjustment and tissue rigidity in smooth cordgrass, Spartina alterniflora (Loisel.). Estuaries Coasts 32:917-925

Touchette BW, Smith GA, Rhodes KL, Poole M (2009b) Tolerance and avoidance: two contrasting physiological responses to salt stress in mature marsh halophytes Juncus roemerianus Scheele and Spartina alterniflora Loisel. J Exp Mar Biol Ecol 380:106-112

Touchette BW, Adams EC, Laimbeer P (2012) Age-specific responses to elevated salinity in the coastal marsh plant black needlerush (Juncus roemerianus Scheele) as determined through polyphasic chlorophyll a fluorescence transients (OJIP). Mar Biol 159:2137-2147

Touchette BW, Kneppers MK, Eggert CM (2019) Salt marsh plants: biological overview and vulnerability to climate change. In: Hasanuzzaman M, Shabala S, Fujita M (eds) Halophytes and climate change: adaptive mechanisms and potential uses. CABI, Boston, MA, p 115-134

Editorial responsibility: Anna Metaxas, Halifax, Nova Scotia, Canada
Wahid A, Gelani S, Ashraf M, Foolad MR (2007) Heat tolerance in plants: an overview. Environ Exp Bot 61:199-223

* Wen X, Qiu N, Lu Q, Lu C (2005) Enhanced thermotolerance of photosystem II in salt-adapted plants of the halophyte Artemisia anethifolia. Planta 220:486-497

*Wilson AM, Evans T, Moore W, Schutte CA, Joye SB, Hughes AH, Anderson JL (2015) Groundwater controls ecological zonation of salt marsh macrophytes. Ecology 96:840-849

Xia J, Li Y, Zou D (2004) Effects of salinity on PSII in Ulva lactuca as probed by chlorophyll fluorescence measurements. Aquat Bot 80:129-137

*Yan K, Chen P, Shao H, Zhao S, Zhang L, Xu G, Sun J (2012) Responses of photosynthesis and photosystem II to higher temperature and salt stress in sorghum. J Agron Crop Sci 198:218-225

*Yang X, Wen X, Gong H, Lu Q and others (2007) Genetic engineering of the biosynthesis of glycinebetaine enhances thermotolerance of photosystem II in tobacco plants. Planta 225:719-733

Yusuf MA, Kumar D, Rajwanshi R, Strasser RJ, TsimilliMichael M, Govindjee, Sarin NB (2010) Overexpression of $\gamma$-tocopherol methyl transferase gene in transgenic Brassica juncea plants alleviates abiotic stress: physiological and chlorophyll a fluorescence measurements. Biochim Biophys Acta 1797:1429-1438

火̌Živčák M, Brestič M, Olšovská K, Slamka P (2008) Performance index as a sensitive indicator of water stress in Triticum aestivum L. Plant Soil Environ 54:133-139

Submitted: January 10, 2020; Accepted: June 19, 2020 Proofs received from author(s): August 21, 2020 